a whizzing noise, rather like the explosive bombs. They blazed furiously, and lit up the whole neighbourhood. We had, however, no great difficulty in extinguishing one with a hand fire-extinguisher. They contain, I imagine, tar, petrol, and much besides.

The rapid succession of the bombs and the spacing apart of the holes showed that the Zeppelin was travelling at high speed at the time, due no doubt to the activity of the anti-aircraft guns. She could not have hoped to hit any specific object, and, indeed, ludicrously failed to hit anything but clay.

The control of the airship was considerable. She was very nimble in endeavouring to evade the searchlights, which, however, had no difficulty whatever in keeping her in the beam.

Observer.

THE KIMMERIDGE OIL-SHALES.

THE rapid extension of the use of oil fuel in the

Navy, coupled with the desirability, for obvious reasons, of securing adequate supplies from home sources, has led to renewed attention being given to the large and easily accessible deposits of oil-bearing shales which have long been known to occur in the vicinity of Kimmeridge, in Dorsetshire, and there is reason to believe that the question of their immediate utilisation has already been urgently pressed upon the notice of the Admiralty.

Assuming that oil of a satisfactory character can be obtained from these shales, there are several considerations which would seem to point to Kimmeridge itself, or some place in its near vicinity, as a suitable spot at which to establish workings, not the least important of which is its proximity to Portland, one of our leading naval stations. Kimmeridge is close to the coast, and although somewhat exposed to gales from the south-west, might be made sufficiently secure as a harbour to enable shipments of the shale to be made to Castletown, or other convenient locality, if it were found impracticable to distil the shale near the place where it is raised. And in any case, should difficulties be found in making the Kimmeridge haven sufficiently safe for vessels to lie at anchor or alongside the jetty that would have to be constructed, Portland Harbour of Kefuge is only a few miles distant, and can be entered at any time of tide, and in any weather.

Many attempts have been made to work the Kimmeridge shales for oil, but hitherto without much success, owing largely to the character of the product and the difficulty of rectifying it into a marketable product as naphtha and illuminating oil. But the nature of oil fuel is wholly dissimilar from that of ordinary burning oil, and its chemical and physical characters are quite different. Nor is the same standard of quality as regards colour, freedom from sulphur, etc., needed in a fuel oil as in an oil intended for illuminating purposes. Hence it is possible that there may be an outlet for the Kimmeridge oil that has hitherto been denied it.

The Kimmeridge shales have long received the attention of geologists, and their extent and distribution have been carefully traced. The outcrop along the Dorsetshire coast begins a mile or two to the west of St. Alban's Head, and, as seen from the sea, forms a very striking natural feature as Kimmeridge is approached. The deposits extend to very considerable distances, and are of unknown depth. To the west they are found at Portland, which, indeed, is known to rest upon them, and they were formerly worked for fuel in the island. They come out here and there along the West Bay, or in its vicinity, as far as Abbotsbury. They have been known in times past to ignite spontaneously, probably owing to the heat developed by the rapid oxidation of marcasite, or some other form of iron pyrites. They extend to the north of Dorsetshire, and have been traced by borings and by outcrops in a north-easterly direction to Norfolk, and through Lincolnshire to the Humber.

In the neighbourhood of Kimmeridge the shale was long used as fuel, and is still so used to a limited extent in the country cottages. In the sixteenth and seventeenth centuries it was worked for alum as at Whitby, and by the same methods, the large quantity of pyrites it contaiits affording the sulphuric acid, whilst other portions served as fuel for evaporation, etc.

The shale seems to have been first worked for oil about 1848 , when small shipments were sent to Weymouth, where the retorting was done-a fact which was held, although unsuccessfully, to invalidate Young's patent for the manufacture of paraffin oil by destructive distillation at a low temperature. At the famous trial Vice-Chancellor Stuart ruled that "the manufacture of offensively-smelling and unmarketable oils from Kimmeridge shales could not be held to be an anticipation of Young's patent." It is, however, interesting to note that Weymouth was the first place in the United Kingdom at which the distillation of shale for the production of hydrocarbon oils was attempted on a manufacturing scale.

In addition to oils of various grades the shales yield notable quantities of ammonia on distillation, a fact which has an important bearing upon their commercial value.

In a highly interesting and suggestive paper recently read to the Institution of Petroleum Technologists, Mr. W. Hardy Manfield has given a very full account of the Kimmeridge oil-shales, their distribution and geological features, and of the various attempts which have been made to turn them to account. The communication also gives a description of the methods of winning oil-shale, of distilling it, and of treating the pro ducts, based upon practical experience. The paper is particularly valuable on account of the author's local knowledge of the Kimmeridge deposits.

The great objection to the use of Kimmeridge oil is due to the large quantity of sulphur it contains, which it has hitherto been practically impossible to remove to a sufficient extent to make the oil marketable. All attempts at purification by the methods of treatment ordinarily usedmainly acid and alkali-are of little value. The

No. 2427 , voL. 97] 
fact is nothing is really known concerning the nature of the combination in which the sulphur is present. It is evidently very firmly held, for the compound or compounds will stand the most drastic treatment without being broken down. There is here a fine field of investigation for any chemist who will grapple with the problem. What seems to be wanted in the first place is that these sulphur compounds should be satisfactorily isolated, and their properties studied. When we know more about them it may be possible to learn how to deal with them. We would invite attention to what is really a very promising subject for inquiry. There can be little doubt that it would yield to systematic attack by modern experimental methods familiar to organic chemists, and there are the possibilities of great material benefits to him who will satisfactorily solve the problem.

\section{THE WASTAGE OF COAL.}

THE Committee for the Investigation of Atmospheric Pollution has just issued its first report, from which it is evident that it has carried out its self-appointed task in a thoroughly scientific and (if the terms are not incompatible) business-like manner. Nineteen towns have undertaken a periodical analysis of the impurities carried down by rain falling on different stations, and also of the constituents of the dust deposited on a specially designed dust gauge of standard dimensions. These results have been tabulated in metric tons per sq. kilo. per month under the headings of insoluble matter (including tar, non-tarry carbonaceous matter, ash), soluble matter (including volatile, combustible, and nonvolatile solids), and sulphuric acid (as sulphate), chlorine (as chloride), and ammonia.

The summary at the end of the report gives a comparative survey of the data from the different localities. These data naturally vary with the nature of the environment, whether industrial, residential, or rural. With the exception of some rather interesting and curious local variations, the general results are such as might be anticipated. In industrial centres, such as Oldham, Bolton, and the Ancoats district of Manchester, the impurities reach a maximum, and yield 25 tons or more of total solids per month, and proportionate quantities of sulphuric acid (3-5 tons), chlorine (0.9-I.5 tons), and ammonia (0.15-0.25 ton), whilst Malvern, situated in an agricultural area, shows a minimum record of less than 5 tons of total solids per month, the monthly mean being $2 \cdot 13$, with $0.50,0.24$, and 0.02 ton of sulphate, chlorine, and ammonia respectively.

This large amount and wide distribution of atmospheric pollution from burning coal (for the impurities are practically all derived from coal) raises two issues: the one a question of injury to animal and plant life, the other one of economy.

Leaving on one side the health question, and confining our attention to the economic problem, which is a pressing one in these days, we look to our coal supply, not only for fuel, but for the raw material for explosives, dyes, synthetic drugs, ferrocyanides, ammonium salts, and, to some extent, sulphuric acid, in every one of which there is a more or less serious shortage. Yet of the two hundred million tons of coal consumed annually, less than forty million tons are burnt economically, that is to say, gasified in gas retorts and by-product coke ovens, whilst the remainder, or 80 per cent., is used, not only as raw fuel in which all the valuable by-products are lost, but through incomplete, and therefore wasteful, combustion contaminate the atmosphere and the soil over an area which may be reckoned in hundreds of square miles.

Is there no way of compassing this absurdly wasteful system of utilising coal? Prof. H. E. Armstrong, in a recent address to the Society of Chemical Industry, suggested that the society should advocate an enactment forbidding the use of raw coal for domestic purposes. We are confident that such an enactment, even if it were made more comprehensive in its scope, would instantly solve the problem of the by-product wastage, and simultaneously clear the atmosphere of smoke without injury or discomfort to home or commercial life.

Faced as we are with the shortage of by-products as well as with the immediate and pressing necessity of restricting expenditure, the subject of fuel economy is one which, along with the wastage on drink, demands more than any other form of economy, on account of the prodigious sums involved, an instant and drastic change in our traditional method of laissez faire.

In the circumstances it is somewhat unfortunate that the Local Government Board, which instituted an inquiry into smoke abatement in the spring of 1914, should have suspended its sittings just at a time when the result of its deliberations might have borne some fruit; and it is to be hoped that a similar committee having wider powers may shortly be appointed to deal with, in addition to smoke abatement, the larger question of the wastage of coal.

J. B. C.

\section{NOTES.}

THE tercentenary of Shakespeare's death is being commemorated this week, and tributes to his genius are being paid in many other parts of the civilised world. The event may not be regarded as of particular scientific significance, yet to let it pass unnoticed in these columns would be to show a want of pride for the memory of the greatest master of our literature. In the Elizabethan age, the cockatrice, the mermaid, the phœnix, the unicorn, and like legendary creatures were realities to the general public, and as such were referred to in the works of the great dramatist and other contemporary writers. We have, for example, in "The Winter's Tale," the line, "Make me not sighted like the basilisk," and in "The Tempest," "Now I will believe that there are unicorns." Not only was more or less credulity given to the existence of these and other fabulous creatures, but a web of mystic lore encircled the most common and best known of beasts, birds, and fishes. But though Shakespeare gave credence to many of the legends he quoted, especially in regard to the animals and plants of distant lands, he had a greater knowledge of natural

No. 2427 , VOL. 97$]$ 